\title{
Analysis of accessibility for buildings of a graduation school - an experiment in ergonomics training curriculum
}

\author{
Acioly, A. S. G. ${ }^{\text {a }}$, Oliveira, M. D. ${ }^{\text {b }}$ Freitas, V. H. F. ${ }^{\mathrm{c}}$ \\ ${ }^{a}$ Design Department, Federal University of Paraiba, CCAE/Campus IV, Mangueiras Avenue, Centro, Rio Tinto, \\ Paraiba,Brazil. (angelica@ccae.ufpb.br) \\ ${ }^{\mathrm{b}}$ Federal University of Paraiba, CCAE/Campus IV, Mangueiras Avenue, Centro, Rio Tinto, Paraíba, Brazil. \\ (moema_oliveira@yahoo.com.br) \\ ${ }^{\mathrm{c}}$ Federal University of Paraiba, CCAE/Campus IV, Mangueiras Avenue, Centro, Rio Tinto, Paraíba, Brazil. \\ (vhfff@gmail.com)
}

\begin{abstract}
This article presents a description of a study experience developed in the Discipline of Supervised Internship of the Industrial Design Course of the Federal University of Paraíba. The study is based on focused on ergonomics analysis and accessibility as an object of study, access into and out of buildings of classrooms and laboratories of the same institution. Among the buildings selected, which encompass where the course is established, is a contemporary building and a renovated building of historical and artistic values for current use. The study is characterized by a description of the objects of study, analysis of the reference literature and recommendations for adjustments in the event of any inconsistency with the accessibility standards. The experience of this supervised training provided an opportunity to perform design activities to a group of students in applied ergonomics, as well as enabling contact with professional practice, adding the contact with the appropriate guidelines governing intervention in historic heritage buildings.
\end{abstract}

Keywords: accessibility, supervised practice, ergonomics.

\section{Introduction}

The Federal University of Paraíba, in a national movement to expand public universities, implemented its fifth campus five years ago on the northern coast of the state. Divided into two units, one in the city of Rio Tinto and the other one in Mamanguape. Campus IV, currently has ten courses, including the course of Industrial Design - Product Design qualification.

The course unit is located in Rio Tinto. The town has great historical and artistic value, because its formation process.

The city was born in 1918 with the arrival of a textile factory, founded by the Lundgren family. Rio Tinto is located $54 \mathrm{~km}$ away the state capital João Pessoa, situated on the northern coast of the state.

Previously the area was known as the "Mill of sloths." Because it is a marshy ground, due to the proximity to the river Mamanguape, the acquisition of territory took place for the small amount of three "contos de réis" - the currency of the time [1].

The purchase of these lands granted the territorial monopoly, preventing their acquisition by others after the recovery, due to the construction of the plant and town of Rio Tinto. [2]

The factory brought immigrants to its construction and operation. It was then installed the Rio Tinto Fabrics Company, which once had the condition of the most complex textile-factory in South America.

With the factory, new textile technologies arrived to the state, people from other cities migrated to Rio Tinto attracted by job opportunities, an urban area developed near the industrial plaint containing spaces to accommodate the growing population, as a church square, school, theater, streets and villages for workers. Rio Tinto can be considered the first planned city in Paraíba. The architecture of some buildings in the city as the Mansion of Lundgrens, church and factory buildings are marked by lines of European style. 
With the collapse of the textile factory, the warehouses of the industrial park were deactivated. The city continued to grow and coexisted from other small business activities for many years.

It is in this historical background that in 2006 the Federal University of Paraíba deploys the Center for Applied Sciences and Education - The Rio Tinto unit started to work in the factory facilities.

In the midst of a nostalgic atmosphere of German architecture, warehouses and administrative environments of the factory were initially adapted in classrooms and laboratories for the Industrial Design, Ecology, Computing, Information Systems and Computer Science, Mathematics and Anthropology graduation courses, until the construction of contemporary buildings for classrooms, labs, residence hall and administrative sectors were completed. These buildings were designed on the grounds destined for the construction of the University, incorporating two of the factory's warehouses, which were disabled since 1983. They would be refurbished and adapted for operation of the Central Lecture Block (Figures 1 and 2), and one for the auditorium and administrative sectors . Special attention is given to this as it was characterized as an intervention in a building under study by IPHAEP, as well as the rest of the city of Rio Tinto.

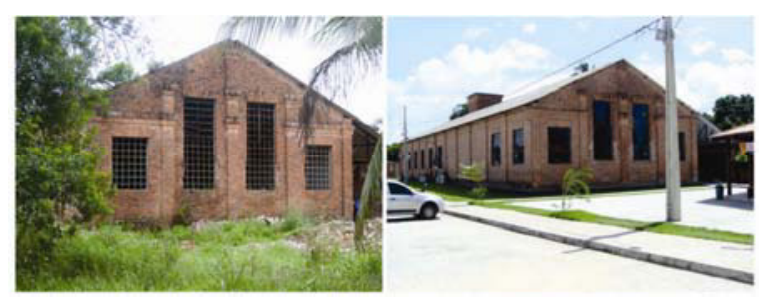

Fig. 01: Building off use / Building remodeled, Actual Classes Central

After the completion of most of the reformation/construction project environments of the Campus, accessibility began to be discussed by the local academic community. One point of interest in this discussion was on the adaptation of the building dating from the 1920s.

The industrial design course features in its curricular structure the Supervised internship discipline, which aims to identify and propose solutions for the real demands of the knowledge areas related to Design. The disciplines of Supervised Internship I and II have an internal character, so their activities are developed in labs / environments inside the university.
Accessibility is an important issue on campus and it represents a real demand, a diagnosis and intervention have been proposed as the first activity of the students in the area of ergonomics. It was proposed to work with the environment, and not specifically products - which are the focus of the course, underpalm than the search for the proper use of environments, at the time the rooms and laboratories were being effectively implemented, could contribute to better use and safety regarding the activities undertaken by pupils and professors.

The experience reported here presents an analysis of the accessibility of a building recently built and another existing one which had had recent architecture interventions, where it was possible to draw a parallel on the issues surrounding access to buildings constructed in such different time spams.

\section{Methodological procedures}

The research and analysis were conducted in a semester and it was as follows:

- Research literature from books, scientific articles on ergonomics, accessibility, universal design, heritage, laws and regulations;

- Photographic survey of the objects of study with the help of digital camera, selecting the images and virtual cataloging;

- Measurement of the objects of study with the help of tape. The measures found were tabulated in a virtual database;

- Generation of charts comparing the state of the art objects of analysis and information arranged in accessibility standards in Brazil, emphasizing the NBR 9050 and NBR 139994;

-Writing and layout of the final report, as well as exhibition material for presentation to the student body and faculty UFPB. Activities performed with the aid of software such as AutoCAD, Corel Draw and Word.

\section{Theoritical approach}

\subsection{Accessibility: concepts and legislation}

Accessibility refers to the right of every citizen to come and go, ensuring the autonomy and independ- 
ence to carry out such activities. Moreover, the right to "come and go," go around town and be able to satisfactorily enjoy urban and building infrastructure reaches the dimensions of social inclusion [3]. From this statement it is clear then how much accessibility is able to transform and democratize the lives of people in diverse and broad aspects such as urban infrastructure, public buildings, homes and products used in day-to-day, communication or information, among others.

The concept of universal design also brings the idea of product, space, furniture and equipment designed for a wider range of users. Universal Design is "one who seeks to meet the widest range of possible variations of anthropometric and sensory characteristics of the population" [4]. In this sense the Ron Mace created seven principles for adaptation projects with affordable stamp [5], they are:

1. Equitable - Equitable Use.

2. Adaptable - Flexible Use.

3. Obvious - Simple and Intuitive Use.

4. Known information - easy to understand.

5. Insurance - Tolerance for Error.

6. Effortlessly - Low Physical Effort.

7. Comprehensive - Division and Space for Approach and Use.

To meet the above provisions, technical standards, laws and decrees exist, to ensure the required specifications, directing as well as enforcing the government and citizens to follow those parameters.

The Federal Decree 5296, which regulated the laws of accessibility (10 098) and Dispatch $(10,048)$, provided technical elements and sets out time limits for public roads, parking lots, public and private buildings to meet accessibility standards.

Technical standards specify the parameters for determining the adaptation of environments and study the needs of its users, and should be known by every professional who designs. There are about fourteen NBR (Brazilian Standards) related to accessibility, one of the most used is NBR 9050, which deals with the Accessibility of Buildings Furniture, Equipment and Urban Spaces.

\subsection{Considerations on the preservation of Historic Heritage}

A simplified definition of what might be considered as historical heritage is: material or immaterial (movable or immovable) goods, natural or built by man that may have a religious meaning and impor- tance of artistic, documental, cultural or aesthetic for the society.

In Brazil, Decree Law No. 25, November 1937 in Article 180 of the Federal Constitution considers historical and artistic heritage all movable and immovable property in the country and whose conservation is of public interest, whether for its connection with the memorabilia of the history of Brazil, or for its exceptional archaeological or ethnographic, literary or artistic values. [6]

Preserving the historical heritage of humanity should be considered a global concern, since this property helps to describe the history of man and earth. Tipping laws, protection for the maintenance and restoration of original features of the monument, define measures for the preservation of historical heritage.

For clarity, tipping is an action which aims, through an administrative act of the Government, to give special protection to certain goods.

Still on heritage protection measures involving school education as a foundation for citizenship formation, the study of historic compounds should be included in education at all levels, especially in history, to inculcate in young minds an understanding and respect for the works of the past and show the role of heritage in modern life [7].

The body responsible for defining the rules of protection and cultural heritage on a global level is the UNESCO (United Nations Organization for Culture, Science and Education). In a hierarchical scale of heritage protection in the first place is UNESCO, the second would be the Institutes of Heritage at the national level, in the case of Brazil, IPHAN (Institute of National Historical and Artistic Heritage), then in a state level in Paraíba, for example, has the IPHAEP (Institute of Historical and Artistic Patrimony of the State of Paraíba) and finally at the municipal level, the town houses.

As for the protection of a monument toppled by a body of national heritage, it can not be structurally modified externally, therefore, not demolished or renovated. The monument can, however, to be restored by skilled professionals in order to preserve the original characteristics. Regarding the importance of heritage preservation and even anthropological value, through some thoughts as:

Such of memory places have material, functional and symbolic characteristics embodied in objects that express the acceleration of time and the deconstruction of the traditional instances of 
preservation and rememberence. Therefore, these places are, above all, residues and traces, constituting memory, temporal and spatial experience, creating and recreating social meanings and individual character. [8]

\section{Accessibility analysis}

Campus IV currently has completed buildings, 01 renovated, 04 in construction and 01 in renovation.

Two buildings were chosen for the analysis, a reformed historic building and other one built approximately two years ago.

The objects of the study were: workspaces, bathrooms, corridors, vertical and horizontal accesses, circulation areas and ranges.

Here are the measurements and diagnostic of each building:

\section{Historic building: classes central}

Composition: Classrooms (06 on ground floor and 6 on the first floor), vertical access ladder, two male and female restrooms, support and advising rooms.

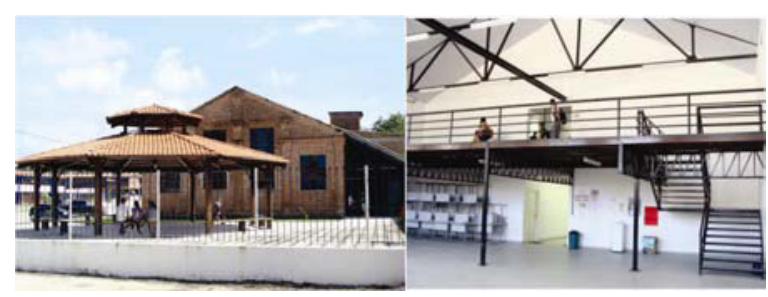

Fig. 02: Facade and lobby of the Classes Central
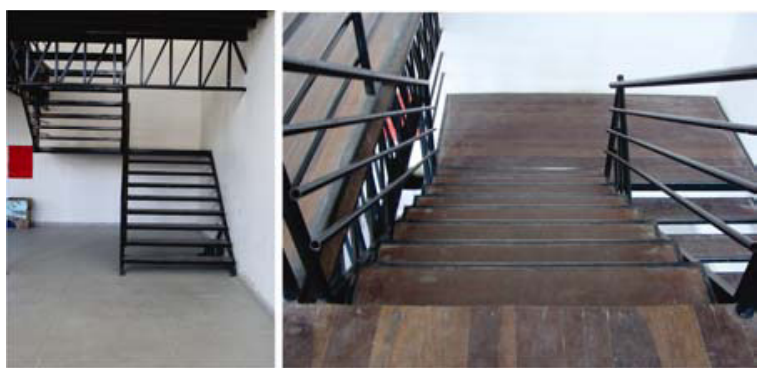

Fig. 03: Vertical Access

Table 01

Diagnostic measurements: vertical access

\begin{tabular}{|l|l|l|l|}
\hline Item & $\begin{array}{l}\text { measure } \\
\text { verified }\end{array}$ & $\begin{array}{l}\text { recom- } \\
\text { mended } \\
\text { measure }\end{array}$ & Situation \\
\hline Step width & 1,83 & 1.73 & Regular \\
\hline Length of step & 0.30 & $0.23-0.36$ & Regular \\
\hline Height of step & 0.17 & 0.17 & Regular \\
\hline $\begin{array}{l}\text { Number of steps } \\
\text { per flight }\end{array}$ & 9 & 10 & Regular \\
\hline Porch Dimensions & $1.50 \times 2.95$ & $1.20 \times 2.95$ & Irregular \\
\hline $\begin{array}{l}\text { Height: right } \\
\text { railing (1 flight })\end{array}$ & - & $0.76-0.86$ & Regular \\
\hline $\begin{array}{l}\text { Height: left railing } \\
\text { (1 flight) }\end{array}$ & 0.80 & $0.76-0.86$ & Regular \\
\hline $\begin{array}{l}\text { Height: right ban- } \\
\text { ister (2nd flight) }\end{array}$ & 0.80 & $0.76-0.86$ & Regular \\
\hline $\begin{array}{l}\text { Height: left hand- } \\
\text { rails (2nd flight) }\end{array}$ & 0.80 & $0.76-0.86$ & Regular \\
\hline $\begin{array}{l}\text { Height: railing on } \\
\text { the porch }\end{array}$ & - & $0.76-0.86$ & Irregular \\
\hline
\end{tabular}

*measured in meters
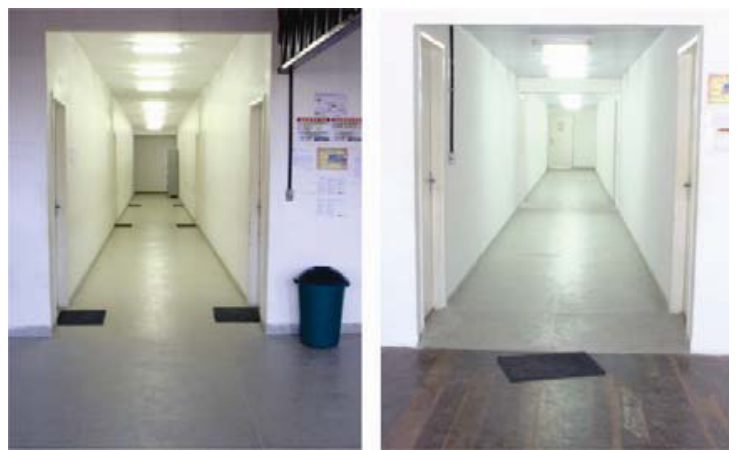

Fig. 04: Inner corridors of the Classes Central Block

Table 02

Diagnostic measurements: hallways

\begin{tabular}{|l|l|l|l|}
\hline Item & $\begin{array}{l}\text { measure } \\
\text { verified }\end{array}$ & $\begin{array}{l}\text { recommended } \\
\text { measure }\end{array}$ & Situation \\
\hline $\begin{array}{l}\text { Width of Corri- } \\
\text { dors }\end{array}$ & 1,05 & 1.37 & irregular \\
\hline
\end{tabular}




\section{Block of Laboratories}

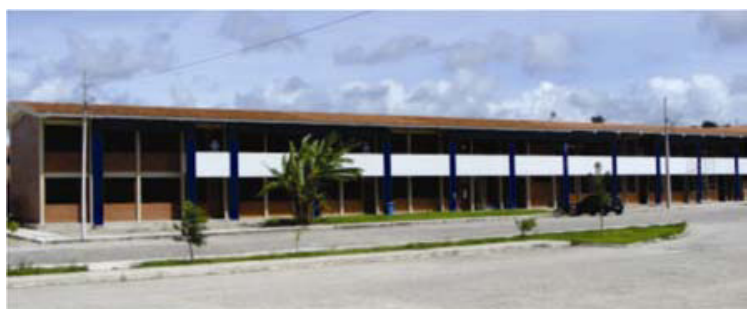

Fig. 05: Block of Laboratories

Composition: 04 laboratories on the ground floor and 04 on the first floor), vertical access ladder, two male and female restrooms, area for lifting platform.

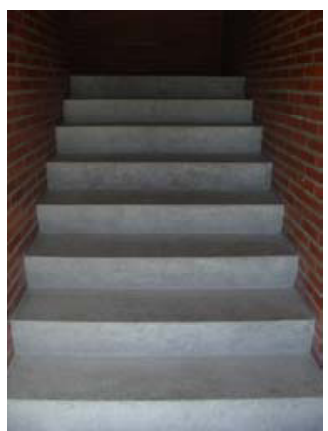

Fig. 06: Stairs in the Block of Laboratories

Table 03

Diagnostic measurements: vertical access

\begin{tabular}{|c|c|c|c|}
\hline Item & $\begin{array}{l}\text { measure } \\
\text { verified }\end{array}$ & $\begin{array}{l}\text { recommended } \\
\text { measure }\end{array}$ & Situation \\
\hline Step width & 1,33 & 1.73 & irregular \\
\hline Length of step & 0.32 & $0.23-0.36$ & Regular \\
\hline Height of step & 0.17 & 0.17 & Regular \\
\hline $\begin{array}{l}\text { Number of steps } \\
\text { per flight }\end{array}$ & 9 & 10 & Regular \\
\hline $\begin{array}{l}\text { Porch } \\
\text { Dimensions }\end{array}$ & $\begin{array}{l}1.33 \times \\
2.85\end{array}$ & $1.20 \times 2.95$ & Irregular \\
\hline $\begin{array}{l}\text { Height: right } \\
\text { railing (1 flight ) }\end{array}$ & - & $0.76-0.86$ & irregular \\
\hline $\begin{array}{l}\text { Height: left } \\
\text { railing (1 flight) }\end{array}$ & - & $0.76-0.86$ & irregular \\
\hline $\begin{array}{l}\text { Height: right } \\
\text { banister ( } 2 \text { nd } \\
\text { flight) }\end{array}$ & - & $0.76-0.86$ & irregular \\
\hline $\begin{array}{l}\text { Height: left } \\
\text { handrails ( } 2 \text { nd } \\
\text { flight) }\end{array}$ & - & $0.76-0.86$ & irregular \\
\hline $\begin{array}{l}\text { Height: railing on } \\
\text { the porch }\end{array}$ & - & $0.76-0.86$ & Irregular \\
\hline
\end{tabular}

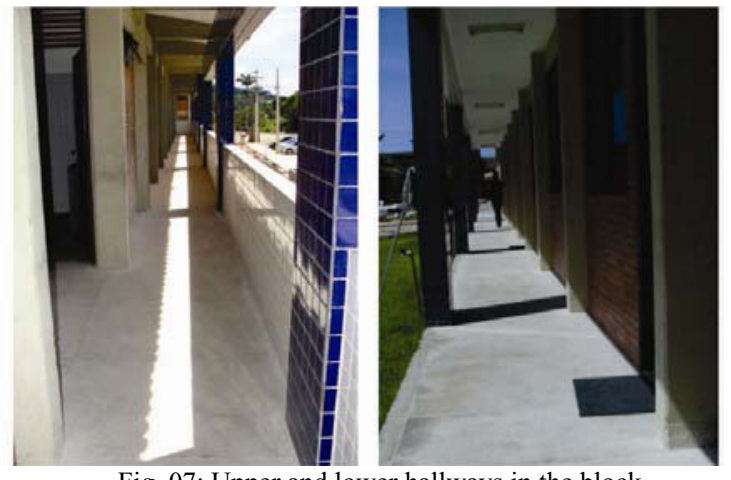

Fig. 07: Upper and lower hallways in the block

Table 04

Diagnostic measurements: hallways

\begin{tabular}{|l|l|l|l|}
\hline Item & $\begin{array}{l}\text { measure } \\
\text { verified }\end{array}$ & $\begin{array}{l}\text { recommended } \\
\text { measure }\end{array}$ & Situation \\
\hline $\begin{array}{l}\text { Width of Corri- } \\
\text { dors }\end{array}$ & 1,85 & 1.37 & regular \\
\hline
\end{tabular}

In the only two buildings analyzed, the vertical access is by stairs, with no other system such as ramps or elevators.

In this case, the lack of adequate access to the top floor for wheelchair users and people with limited movement indicates the need for lifting platforms with handrails, which should have an angle of three degrees and slip free floors, and should have a contrasting color on the floor according to NBR13994.

The results observed by describing the state of the art in an instrumentalized manner (photographs and measurements) compared with data tabulated by the accessibility laws, guidelines on ergonomic workspaces, and provided anthropometric tables, verified that part of the study subjects had some inconsistency with these regulations. That is, both in the historical building went recently under architectural intervention, as the new building were not adapted to use, to the fullness of ISO 9050 and 13,994 in equipment and internal structures.

\section{Conclusion}

The experience of Supervised Internship I, in many respects could be considered an activity of great value. 
First as a practical experience of some of the possible professional activities, the accessibility analysis. Currently social inclusion is deservedly getting more attention from different levels and spaces, which showed that the accessibility of public spaces such as the University must be properly contextualized to accommodate people with special needs, disabilities or reduced mobility. Thus, the experience of the internship also had a social character, the conscience about the other one next to you. Extending the social character of this internship to another level, there was also an exercise in citizenship when it was necessary to pursue the artistic and historical aspects of where Campus IV of the Federal University of Paraíba is located.

The activity performed in a technical and systematic way, made it possible to come across the rules that govern design stages of environments and equipment, as well as an exercise in reading architectural plans. These facts strengthen the premises of ergonomics, that one of an interdisciplinary science, in this specific study, it was found a close link between architecture and design and between design and history.

As in any study, it is unfortunate to verify equipment or objects of study, the gaps in both projects concerning the design and execution of spaces and facilities for public use at the university. It is a fact that at some point it could cause discomfort to the user. A sad conclusion to reflect on how many times the lack of inclusion in public spaces as an EI (educational institution) can be observed.

Finally, it is worth noting the intention of this study in the contribution of the creation and improvement of EI, which was made by the Industrial Design graduates, as a means of a practical and tangible contribution to the UFPB.

\section{References}

[1] Silva, M.G., Lima, E. C., Conflitos Territoriais No Municipio De Rio Tinto/Pb: O Caso Da Retomada Das Terras Da Aldeia Monte Mor. Anais do congresso XVI Encontro nacional dos Geógrafos, Porto Alegre, 2010

[2] Panet, Amélia. Rio Tinto: estrutura urbana, trabalho e cotidiano/Amélia Panet ET AL. João Pessoa. UNIPÊ Editora, 2002.

[3] Oliveira, A.; Batista, V.; Dorneles, V.; Bins Ely, V. "A percepção e uso do espaço sob a ótica das pessoas com necessidades especiais: um estudo de caso. In: 50. ERGODESIGN, Rio de Janeiro: LEUI/PUC-Rio, 2005. CD-

[4] ABNT - Associação Brasileira de Normas Técnicas. NBR 9050: Acessibilidade de Pessoas Portadoras de Deficiência a
Edificações, Espaço, Mobiliário e Equipamento Urbano. Rio de Janeiro: ABNT. 2004.

[5] Carletto, Ana Claudia; CAMBIAGHI, Silvana. Desenho Universal: um conceito para todos. Edição Mara Gabrilli, s/d.

[6] DECRETO-LEI $\mathrm{N}^{\mathrm{o}}$ 25. Disponível em: < http:// www. planalto.gov.br/ccivil 03/decreto-lei/Del0025.htm $>$. Acesso em: 28 de julho de 2011.

[7] Caju, Náhya M. Identificando o patrimônio. João Pessoa: Idéia, 2005.

[8] Cerbina, Ana L. F. Algumas considerações sobre a linguagem gráfica do centro do Rio de Janeiro. In: Congresso Brasileiro de Pesquisa e Desenvolvimento em Design, 4, Rio Grande do Sul, 29 de out. a 01 de nov. de 2000. Anais do $4^{\circ}$ Congresso Brasileiro de Pesquisa e Desenvolvimento em Design. Rio Grande do Sul: Feevale, 2000. p 295 -301.

\section{Sources Consulted}

IIDA, Itiro. Ergonomia: Projeto e Produção. $2^{\mathrm{a}}$ Ed. São Paulo: Edgard Blucher, 2005.

PANERO, Julius: ZELNIK, Martin. Las dimensiones humanas em los espacios interiores. 10 ${ }^{\mathrm{a}}$ Ed. Barcelona; Gustavo Gili. 2002.

ASSOCIAÇÃO BRASILEIRA DE NORMAS TÉCNICAS ABNT. NBR 9050: Acessibilidade a edificações, mobiliário, espaços e equipamentos urbanos. Rio de Janeiro, 2004.

ASSOCIAÇÃO BRASILEIRA DE NORMAS TÉCNICAS ABNT. NBR 13994: Elevadores de passageiros - elevadores para transporte de pesssoa portadora de deficiência. Rio de Janeiro, 2000 .

BRASIL. Decreto-lei n. ${ }^{\circ} 25$, de 30 de novembro de 1937. Organiza a proteção do patrimônio histórico e artístico nacional.

BRASIL. Lei $\mathrm{n}^{\mathrm{o}} 10.098$, de 19 de dezembro de 2000. Estabelece normas gerais e critérios básicos para a promoção da acessibilidade das pessoas portadoras de deficiência ou com mobilidade reduzida.

BRASIL. Decreto 5296, de 2 de dezembro de 2004. Regulamenta as Leis 10048 , de 8 de novembro de 2000 , que dá prioridade de atendimento às pessoas que especifica, e 10098, de 19 de dezembro de 2000, que estabelece normas gerais e critérios básicos para a promoção da acessibilidade das pessoas portadoras de deficiência ou com mobilidade reduzida, e dá outras providências.

Henry Dreyfuss Associates. As Medidas do Homem e da Mulher Fatores Humanos em Design. Artmed, 2005.

IIDA, Itiro. Ergonomia: Projeto e Produção. Rio de Janeiro: Edgard Blücher, 2000 ( $6^{\mathrm{a}}$ reimpressão).

INSTITUTO DO PATRIMÔNIO ARTÍSTICO E NACIONAL. Instrução Normativa n. ${ }^{\circ} 1$, de 25 de novembro de 2003. Dispõe sobre a acessibilidade aos bens culturais imóveis acautelados em nível federal, e outras categorias, conforme especifica.

OLIVEIRA, Antônia Maria de Fátima. Acessibilidade compração das leis dos países do Mercosul. 2008 Disponível em: http://bd.camara.gov.br/bd/bitstream/handle/

bdcamara/3345/acessibilidade_mercosul_oiliveira.pdf?sequence $=1$. Acesso em 2011. 